\title{
A Novel Approach for Pathology Test using Android App
}

\author{
Nidhi Laddha \\ Department of Computer Science and \\ Engineering, \\ G. H. Raisoni College of Engineering, \\ Nagpur, India
}

\author{
Shubhangi Giripunje, PhD \\ Associate Professor \\ Department of Electronics Engineering, \\ G. H. Raisoni College of Engineering, \\ Nagpur, India
}

\begin{abstract}
Pathology is related to analyzing symptoms through analysis of blood and urine for early detection, diagnosis and prevention of diseases. Patient submitsblood and urine samples in pathology for diagnosis of diseases and report for the same is provided. But it is not possible to provide pathology facility everywhere. Patients need to travel to pathology laboratory on their own for giving their blood and urine samples. It is infeasible some times for patients to go empty stomach and give urine and blood samples to pathology laboratory and then waits for reports. To solve this problem, hardware is developed to give readings of particular tests after analyzing blood under different parameters. We have developed an android app which interfaces with the hardware and provides results, analyze them and store in their phone and on the server, the results are available whenever required in the form of report. It helps patients to understand the severity of disease and take further action.
\end{abstract}

\section{Keywords}

Pathology, android app, interfacing

\section{INTRODUCTION}

Pathology is related to the diagnosis of disease based on the analysis of blood and urine. Pathologists work in collaboration with medical technologists and physicians. Pathology is concerned with analyzing known clinical abnormalities that are markers for diseases [8].

Pathology investigations are important part of the clinical consultation whichindicates that $70-80$ per cent of all health care decisions affecting diagnosis or treatment involve a pathology investigation. Pathology is essential to the prevention, early detection, diagnosis and treatment of disease [8].

Hospitals provide pathology lab facility where patients can give blood and urine samples for diagnosis of diseases under doctor's supervision. So, patients will get reports in the same hospital. But as most of area in our country is rural based, not all hospitals in rural area can provide pathology facility in their hospitals. Patients need to travel to pathology laboratory on their own for giving their blood and urine samples. It is infeasible some times for patients to go empty stomach and give urine and blood samples to pathologylaboratory and then waits for reports. Sometimes pathology lab assistant come home to take samples but this is not possible always. To solve this issue, there is a need of some mechanism which can help such patients to get their reports done with minimum efforts.

The glucometers available today takes blood and provides readings. Layman users won't understand anything from its reading. There is need to keep manual record of the readings. This scenario motivates us to bring such system that will give readings as glucometers give plus it should be able to save results as well as reports should always be available with patients and primary analysis of those reports which indicate severity of disease.

Considering all discussed issues, a mobile app 'PATHO' has been developed, which interfaces with the hardware which shows:

- Type of sample is to be considered,

- Hardware which test parameter to check in the given sample

- Collect results from hardware.

- Display and analyze the results. Show detailed report for given test.

\section{OBJECTVE}

The objective of research work is not only getting accurate readings for given test parameter through app but also to analyze the results under different parameters like age, gender, medical history to understand the severity of results obtained.

The research work carried out is based on following objectives:

- To study and classify different test parameters under different criterion like age, gender and medical history.

- Investigate the severity of results obtained.

- Provide some details to users in user-friendly way.

Store results in database so that patient can get its previous results when required.

\section{SYSTEM DESCRIPTION}

Proposed methodology is divided into four phases.

1. Decides type of tests to be undertaken. Get its standard values.

2. Study influence of different parameters like age, gender and medical history on human body for any particular disease and decides its severity level.

3. Development of android app which can interface with the hardware to ask it samples to be processed for specified list of tests and to get results back.

4. Store results obtained in app and also able to send the results to server to get monitored by doctor. 


\subsection{Decides type of tests to be undertaken}

In this section, we decide type of test to be carried out for blood and urine.

Fig. 1 shows flow of test.

\begin{tabular}{|l|l|l|}
\hline Age Group & $\begin{array}{l}\text { Normal } \\
\text { Range } \\
\text { (mg/dl) }\end{array}$ & $\begin{array}{l}\text { Normal } \\
\text { Range } \\
(\mathbf{m m o l} / \mathbf{L})\end{array}$ \\
\hline Premature Infants & $40-65$ & $2.2-3.6$ \\
\hline 0-2 years & $60-110$ & $3.3-6.1$ \\
\hline 2 years-Adults & $60-115$ & $3.3-6.4$ \\
\hline Adults & $70-110$ & $3.3-6.1$ \\
\hline
\end{tabular}

\begin{tabular}{|l|l|l|}
\hline Age Group & Range $(\mathbf{m g} / \mathbf{d l})$ & $\begin{array}{l}\text { Range } \\
(\mathbf{m m o l} / \mathbf{L})\end{array}$ \\
\hline Infants & $<40$ & $>2.2$ \\
\hline Adults :Male & $<50$ & $<2.75$ \\
\hline Adults: Female & $<40$ & $<2.2$ \\
\hline
\end{tabular}

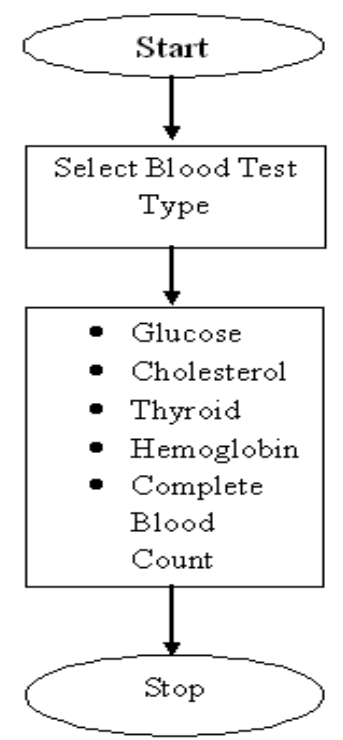

Fig 1: Decide type of test to be carried out

\subsection{Study influence of different parameters viz. age, gender and medical history on human body}

\subsubsection{Glucose}

A blood glucose test measures the amount of a sugar called glucose in a sample of blood. Glucose test helps to manage diabetes. Increased glucose levels may be found in different conditions like diabetes, hyperthyroidism, stress, and renal failure. Low glucose levels are associated with hypothyroidism, severe liver disease etc. To find amount of glucose in blood, 3 glucose tests are performed:

i. Fasting blood sugar

ii. Post meal sugar

iii. Random sugar

\section{Fasting Blood Sugar}

Fasting for at least 8 hours

$\square$ Normal Person:

Reference Range

Panic Range

$\square$ Diabetic Patient: 80-130 mg/dl (4.5-7.2 mmol/L)

Post Meal Sugar:

After 2 hours from beginning of meal

$\square$ Normal person without diabetes:

$<140 \mathrm{mg} / \mathrm{dl}(7.8 \mathrm{mmol} / \mathrm{L})$

$\square$ Diabetic Patient:

$<180 \mathrm{mg} / \mathrm{dl}(10.0 \mathrm{mmol} / \mathrm{L})$

\section{Random Sugar:}

Anytime in 24 hours

$\square$ Normal person without diabetes:

$<140 \mathrm{mg} / \mathrm{dl}(7.8 \mathrm{mmol} / \mathrm{L})$

Pre-diabetic Patient: 140-199 mg/dl

Diabetic patient: $>200 \mathrm{mg} / \mathrm{dl}$

All the three values of blood sugar are to be monitored to decide whether patient is suffering from diabetes and/or to control diabetes as it is life threatening disease. One needs to monitor required values both for normal person as well as diabetic patient. When values so obtained are below or higher than given range, patient needs to consult doctor immediately.

\subsubsection{Cholesterol}

Cholesterol is found in our body as a part of cell membranes, lipoproteins and steroid hormones. It comes from diet and our body also makes it. It is required for proper functioning of body. However, higher values lead to heart disease.

This test includes:

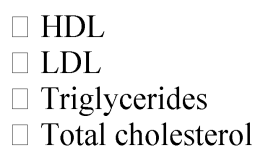

\section{HDL}

High density lipoprotein (HDL) is good cholesterol that assists in maintaining arterial blood vessels clear. It helps to circulate blood without restrain. This test is ordered more frequently for people having high risk of heart diseases. This value should be as high as possible to decrease the risk of heart disease.

\begin{tabular}{|c|c|c|c|c|c|c|}
\hline \multirow[t]{2}{*}{$\begin{array}{c}\text { Age } \\
\text { Group }\end{array}$} & \multicolumn{2}{|c|}{$\begin{array}{c}\text { Acceptable } \\
\text { Range }\end{array}$} & \multicolumn{2}{|c|}{$\begin{array}{c}\text { Borderline } \\
\text { Range }\end{array}$} & \multicolumn{2}{|c|}{$\begin{array}{c}\text { High risk } \\
\text { Range }\end{array}$} \\
\hline & $\begin{array}{c}\mathrm{mg} / \\
\mathrm{dl}\end{array}$ & $\begin{array}{l}\mathrm{m} \\
\mathrm{mo} \\
\mathrm{l} / \mathrm{L}\end{array}$ & $\mathrm{mg} / \mathrm{dl}$ & $\begin{array}{c}\mathrm{mmol} \\
/ \mathrm{L}\end{array}$ & $\mathrm{mg} / \mathrm{dl}$ & $\begin{array}{c}\mathrm{mmol} \\
/ \mathrm{L}\end{array}$ \\
\hline $\begin{array}{l}\text { Children/ } \\
\text { Teens/ } \\
\text { Young } \\
\text { Adults }\end{array}$ & $>45$ & $\begin{array}{c}1.1 \\
7\end{array}$ & $40-45$ & $\begin{array}{l}1.04- \\
1.17\end{array}$ & $<40$ & 1.04 \\
\hline $\begin{array}{l}\text { Adults: } \\
\text { Male }\end{array}$ & $>60$ & $\begin{array}{c}1.5 \\
5 \\
\end{array}$ & $40-45$ & $\begin{array}{l}1.0- \\
1.3 \\
\end{array}$ & $<40$ & 1.04 \\
\hline $\begin{array}{l}\text { Adults: } \\
\text { Female }\end{array}$ & $>60$ & $\begin{array}{c}1.5 \\
5\end{array}$ & $50-59$ & $\begin{array}{l}1.3- \\
1.5\end{array}$ & $<50$ & 1.3 \\
\hline
\end{tabular}




\begin{tabular}{|l|c|c|l|l|l|c|}
\hline $\begin{array}{c}\text { Age } \\
\text { Group }\end{array}$ & \multicolumn{2}{c|}{$\begin{array}{c}\text { Acceptable } \\
\text { Range }\end{array}$} & \multicolumn{2}{c|}{ Borderline Range } & \multicolumn{2}{c|}{ High risk } \\
\hline & $\mathrm{mg} / \mathrm{dl}$ & $\begin{array}{c}\mathrm{mmol} \\
\mathrm{L}\end{array}$ & $\mathrm{mg} / \mathrm{dl}$ & $\mathrm{mmol} / \mathrm{L}$ & $\mathrm{mg} / \mathrm{dl}$ & $\begin{array}{c}\mathrm{mmol} \\
/ \mathrm{L}\end{array}$ \\
\hline $\begin{array}{l}\text { Children/ } \\
\text { Teens }\end{array}$ & $<110$ & 2.85 & $\begin{array}{l}110- \\
129\end{array}$ & $\begin{array}{l}2.85- \\
3.34\end{array}$ & $>130$ & $>3.36$ \\
\hline $\begin{array}{c}\text { Young } \\
\text { Adults }\end{array}$ & $<120$ & 3.1 & $\begin{array}{l}120- \\
159\end{array}$ & $\begin{array}{l}3.10- \\
4.11\end{array}$ & $>160$ & $>4.12$ \\
\hline $\begin{array}{l}\text { Adults: } \\
\text { Male \& }\end{array}$ & & & & & & \\
Female & $0-129$ & 3.34 & $130-$ & $3.37-$ & & \\
\hline
\end{tabular}

Normal Range:

\begin{tabular}{|l|l|l|l|}
\hline $\begin{array}{l}\text { Age } \\
\text { Group }\end{array}$ & T3 & T4 & TSH \\
\hline New Born & $105-245$ & $11.8-22.6$ & $1-3$ \\
\hline $\begin{array}{l}\text { Up to } 20 \\
\text { years }\end{array}$ & $82-213$ & $6.4-13.3$ & $0.7-6.4$ \\
\hline Adults & $60-200$ & $4.5-12$ & $0.3-5.5$ \\
\hline $\begin{array}{l}\text { During } \\
\text { Pregnancy }\end{array}$ & $70-204$ & $4.2-11.8$ & $0.2-5.7$ \\
\hline
\end{tabular}

\section{LDL}

Low density lipoprotein (LDL) is bad cholesterol that increases risk of heart diseases. It is used to monitor effectiveness of lipid lowering therapy and to decide the risk of developing heart diseases. This value should be as low as possible.

\section{Triglycerides}

These are called fats in blood. They are used to give energy to body and are end products of digesting and breaking down fats in blood. This test is important because we don't get any symptoms when these values are high, it leads to heart disease.

\section{Total Cholesterol}

This gives total amount of cholesterol in blood. It is also called as serum cholesterol, scored depending on danger of cardiovascular illness. It is calculated in $\mathrm{mg} / \mathrm{dl}$ as:

\section{Total cholesterol=HDL+LDL+ $(0.2 *$ Triglycerides $)$}

\begin{tabular}{|c|c|c|c|c|c|c|}
\hline \multirow[t]{2}{*}{ Age Group } & \multicolumn{2}{|c|}{$\begin{array}{l}\text { Acceptable } \\
\text { Range }\end{array}$} & \multicolumn{2}{|c|}{ Borderline Range } & \multicolumn{2}{|c|}{ High risk } \\
\hline & $\begin{array}{l}\mathrm{mg} / \\
\mathrm{dl}\end{array}$ & $\begin{array}{l}\text { mmol/ } \\
\mathrm{L}\end{array}$ & $\mathrm{mg} / \mathrm{dl}$ & $\mathrm{mmol} / \mathrm{L}$ & $\mathrm{mg} / \mathrm{dl}$ & $\begin{array}{l}\mathrm{mmol} / \\
\mathrm{L}\end{array}$ \\
\hline $\begin{array}{l}\text { Children: } \\
\text { New Born - } \\
9 \text { years } \\
\end{array}$ & $<75$ & 0.85 & $75-99$ & $0.85-1.12$ & $>100$ & 1.13 \\
\hline $10-19$ years & $<90$ & 1.02 & $90-129$ & $1.02-1.46$ & $>130$ & 1.47 \\
\hline $\begin{array}{l}\text { Young } \\
\text { adults }\end{array}$ & $\begin{array}{l}<11 \\
5\end{array}$ & 1.3 & $115-149$ & $1.30-1.68$ & $>150$ & 1.7 \\
\hline $\begin{array}{l}\text { Adults: } \\
\text { Male and } \\
\text { Female }\end{array}$ & $\begin{array}{l}<15 \\
0\end{array}$ & 1.7 & $150-199$ & $1.7-2.2$ & $>200$ & 5.6 \\
\hline
\end{tabular}

\begin{tabular}{|c|c|c|c|}
\hline Age Group & $\begin{array}{l}\text { Acceptable } \\
\text { Range }\end{array}$ & $\begin{array}{l}\text { Borderline } \\
\text { Range }\end{array}$ & $\begin{array}{l}\text { High risk } \\
\text { Range }\end{array}$ \\
\hline $\begin{array}{c}\text { Children : } \\
\text { 2-19 years }\end{array}$ & $<170$ & $170-199$ & $>200$ \\
\hline $\begin{array}{c}\text { Adults :Male } \\
\text { and Female }\end{array}$ & $<200$ & $200-240$ & $>240$ \\
\hline
\end{tabular}

\subsubsection{Thyroid}

Thyroid function tests used to find the working of thyroid gland. Tests include T3, T4, and TSH. The thyroid gland secretes two major hormones: triiodothyronine (T3) and thyroxin (T4). Condition is called hypothyroidism if gland is unable to secret required level of hormone. If thyroid gland secrets beyond normal level, it is called hyperthyroidism.

$\mathrm{T} 3$ and $\mathrm{T} 4$ are measured in nano grams and micrograms per deciliter, TSH measured in micro International units per milliliter.

\section{- Hypothyroidism}

This condition is found when thyroid gland is unable to secret required level of hormones. In this, T3 and T4 are below normal range and TSH is 6 to 60 times more than normal range.

\section{Effect of Age:}

It is normally seen in elder person.

\section{Effect of gender:}

Seen more in females as compared to males.

\section{Effect of Medical History:}

Females suffering from delayed or scanty menstrual cycles and unexplained infertility or miscarriages should be tested for hypothyroidism. During pregnancy, T3 and T4 levels must be optimum, deficiency may cause irreversible damages to both physical and mental growth of fetus.

\section{Symptoms:}

Low T3 and T4 levels results in abnormally low metabolic rate. Mental and physical processes become slower and heat production is reduced.

Causes:

Prolonged Iodine deficiency, deficiency of TSH and surgical removal of excess thyroid tissue.

\section{$\square$ Hyperthyroidism:}

This condition is found when thyroid gland secrets beyond normal level of hormones. In this, T3 and T4 are higher than normal range and TSH is low.

Effect of Age:

Above 40 years

Effect of gender:

Seen more in females.

Effect of Medical History:

Women having abnormalities in menstrual cycles, who have given birth recently, who have lost/gained more than $2 \mathrm{~kg}$ weight in 2-3 months, who feel exhausted and fatigued, who have very high or low pulse rate

Symptoms:

Excessive heat production, increased metabolic rate, physical restlessness, enlargement of thyroid gland.

Causes:

Having family history of thyroid and having high or low cholesterol. 


\subsubsection{Hemoglobin}

Hemoglobin carries oxygen and returns carbon dioxide to the lungs. It gives red color to blood. It is expressed in grams (gm) per deciliter (dL).

\section{Effect of age:}

Hemoglobin range varies with age.

Effect of gender:

Range varies according to gender.

Effect of Medical history:

Hemoglobin range found increased in congenital heart diseases and found decreased in pregnancy.

Normal Values:

\begin{tabular}{|l|l|}
\hline Age Group & Standard Ranges \\
\hline Infants & $13.5-19.5$ \\
\hline Children (up to 1 year) & 11 to 13 \\
\hline $10-12$ years & $11.5-14.5$ \\
\hline Adult Male & 14 to 18 \\
\hline Adult Female & 12 to 16 \\
\hline Males after middle age & 12.4 to 14.9 \\
\hline Females after middle age & 11.7 to 13.8 \\
\hline
\end{tabular}

\subsubsection{Complete Blood Count}

It is a blood test used to evaluate overall health and detect wide ranges of disorders. This test is ordered when patient shows symptoms that may be related to disorders that affect blood cells. This test evaluates:

$\square$ Hemoglobin

$\square$ Hematocrit

$\square$ Red blood cells count

$\square$ White blood cells count

$\checkmark$ Platelet count

\subsubsection{Hematocrit:}

$\square$ It is also called Packed Cell Volume (PCV).

$\square$ It is used to express amount of packed red blood cells, expressed as \% of total blood volume.

$\square$ Increase in PCV values found in: dehydration and congenital heart diseases.

$\square$ Decrease in PCV values found in: Anemia

$\checkmark$ Normal Values:

\begin{tabular}{|l|l|}
\hline Male & $42-52 \%$ \\
\hline Female & $36-48 \%$ \\
\hline Pregnancy & $23-37 \%$ \\
\hline
\end{tabular}

\subsubsection{Red Blood Cells Count}

$\square$ Counts red blood cells,also known as erythrocyte count

$\square$ Test is important because RBC contains hemoglobin, oxygen carrier ,in blood

$\square$ Number of RBC you have affect oxygen your tissue receives.

$\square$ Important in diagnostic hematology and also to detect cancers

$\square$ Permits MCV and $\mathrm{MCH}$ value calculations

$\square$ Increase in values results in: joint pain, itching skin, sleep disturbance

$\square$ Decrease in values results in increased heart rate, pale skin, headaches, leukemia, bone marrow failure, anemia, pregnancy, thyroid disorder and malnutrition

Normal Range

\begin{tabular}{|l|l|}
\hline Adult Male & $4.5-6$ million cells/cu mm \\
\hline Adult: Female & $4.0-4.5$ million cells/cu mm \\
\hline New Born & $6.5-7.25$ million cells/cu mm \\
\hline
\end{tabular}

\section{RBC Indices:}

a. MCV: Mean Corpuscular Volume

$\square$ Gives average volume of red cells.

Calculated as

$\mathrm{MCV}=(\mathrm{PCV} * 10) / \mathrm{RBC}$ in million

$\square$ Normal range:

\section{2-92 cu mm (fl /red cell)}

$\square$ Low MCV indicates microcytic (small average RBC size) ,normal MCV indicates normocytic( normal average RBC size) and large MCV indicates macrocytic(large average RBC size)

\section{b. MCH :Mean Corpuscular Hemoglobin}

$\square$ Gives average amount of hemoglobin found in red blood cell.

$\square$ Calculated as:

\section{$\mathrm{MCH}=(\mathrm{Hb} * 10) / \mathrm{RBC}$ in million}

$\square$ Normal Range:

\section{7-32 pg ( 1 pg=10-12 gm)}

High $\mathrm{MCH}$ results in macrocytic anemia, caused by insufficient vitamin B12. Higher $\mathrm{MCH}$ values are needed to be treated on primary basis.

c. MCHC: Mean Corpuscular Hemoglobin

\section{Concentration}

Average concentration of hemoglobin in red blood cells. 
It is used to diagnose type, cause and severity of anemia.

Calculated as:

\section{$\mathrm{MCHC}=\left(\mathrm{Hb}^{*} \mathbf{1 0 0}\right) / \mathrm{PCV} \%$}

$\square$ Normal Rage:

\section{$32-36 \%$}

Decrease in level: hypochromic anemia

( RBC do not have enough hemoglobin to function properly.

Increase in level: macrocytic anemia (blood with insufficient concentration of hemoglobin.)

\subsubsection{White Blood Count:}

It helps to fight against infections and also to detect hidden infections.

$\square$ Test is recommended for persistent body aches, fever and headaches. immune deficiencies and blood disorders.

$\square$ also helps to doctors to find effectiveness of chemotherapy or radiation treatment in cancer patients

$\square$ Normal Range:

\begin{tabular}{|l|l|}
\hline $\begin{array}{l}\text { Adults (Male and } \\
\text { Female) }\end{array}$ & $4000-10000 / \mathrm{cu} \mathrm{mm}$ \\
\hline At birth & $10000-25000 / \mathrm{cu} \mathrm{mm}$ \\
\hline $1-3$ years & $6000-18000 / \mathrm{cu} \mathrm{mm}$ \\
\hline $4-7$ years & $6000-15000 / \mathrm{cu} \mathrm{mm}$ \\
\hline $8-12$ years & $4500-13500 / \mathrm{cu} \mathrm{mm}$ \\
\hline
\end{tabular}

Increase in total leukocyte count of more than $10000 / \mathrm{cu} \mathrm{mm}$ is known as leukocytosis.

\section{Causes of leukocytosis:}

a. bacterial, viral and protozoal infections

b. At birth, about $18000 / \mathrm{cu} \mathrm{mm}$, drops gradually

c. $12000-15000 / \mathrm{cu} \mathrm{mm}$ during pregnancy, returns to normal after delivery.
d. High temperature
e. Severe Pain
f. Muscular Exercise
g. Stress
h. asthma

Decrease in total leukocyte count below $4000 / \mathrm{cu} \mathrm{mm}$ is known as leukopenia.

\section{Causes of leukopenia:}

a. Viral and bacterial infections

b. Leukemia

c. Anemia

d. Bone marrow depression

e. HIV

f. Severe infections g. Liver diseases

\subsubsection{Platelet Count}

$\square$ Platelets are used to clot blood during bleeding. If we don't have enough platelet in body, our body can't clot blood.

$\square$ This test is requested in investigation f bleeding disorders.

$\square$ Normal Range:

\section{0-500000/cu mm}

Low count causes:

a. nose bleeds

b. bleeding gums

c. heavy menstrual bleeding

d. blood in stools and urine

e. bleeding from wounds

Low count is quite risky, may lead to death

High platelet count is a condition in which blood contains more platelets than normal.

$\square$ High platelet count is also sometimes dangerous, can be a symptom of another disease or infections such as anemia, infection or cancer.

\subsection{Development of android app which can interface with the hardware \\ a. Interfacing of hardware and software}

The hardware has Bluetooth connectivity provision which is useful to connect it with other hardware and software as well. Once we start the hardware, its Bluetooth get automatically started. This technology is used to discover and transfer data between nearby devices.

It will include the following steps:

$\square$ Enable Bluetooth of an app.

$\square$ Display a list of nearby Bluetooth devices.

Select the hardware

$\square$ Establish the connection amongst devices

$\square$ After connection has been established successfully, proceed towards app to enter patient details and select test.

Select test and get its value from hardware and display in investigation report 


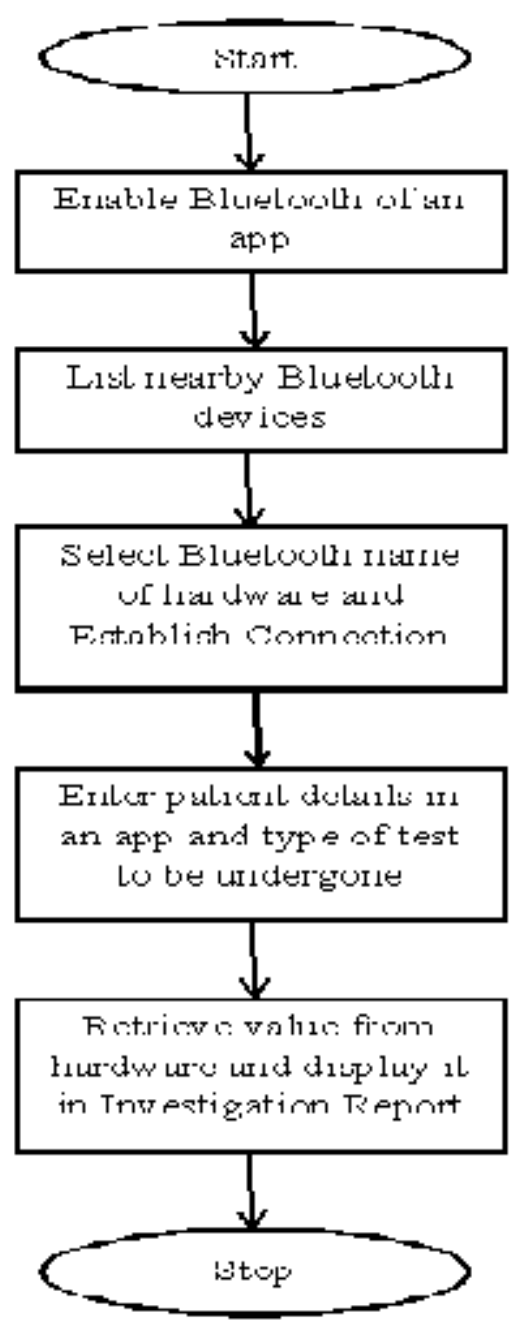

Fig 2: Implementation plan

\subsection{Store results obtained in app and also able to send to server}

After analysis of results under different parameters, we reach to primary conclusion explaining severity level of results obtained and then show these results in report form in database for future purpose.

Database is included for storing results in an app and also on server. It will include following steps:

- As we are developing app for all users, we are asking patients to sign up to the app, in the very similar way, we signup to other apps.

- We have developed server side database using 'WAMP server' (Server supporting Windows Apache Mysql PHP) where we can store personal details of patient in 'personal' table.

- Once user signs up, we generate its id in database which will be useful for further references. User will be allowed to access app using its username and password.

- We provide 'forgot password' option also. User can change password which will be reflected at server database.
- Once user signs in, s/he can enter its personal details and then select type of sample on which test to be carried out.

- Then s/he will be asked to decide type of test.

- Then data will be collected from hardware and displayed on screen.

- $\quad$ This value will be stored in its own database as well as on server, if patient wants to.

\section{RESULT AND DISCUSSION}

In this section, result obtained are discussed.We have designed a module which detects hardware device and take user details and generate blood test report. Fig3 shows signing up in an app.Fig 5 shows scanning of hardware device. Interfacing with hardware is shown in Fig. 6. User details are taken which is shown in Fig. 7 and blood test report is generated as shown in Fig.8.

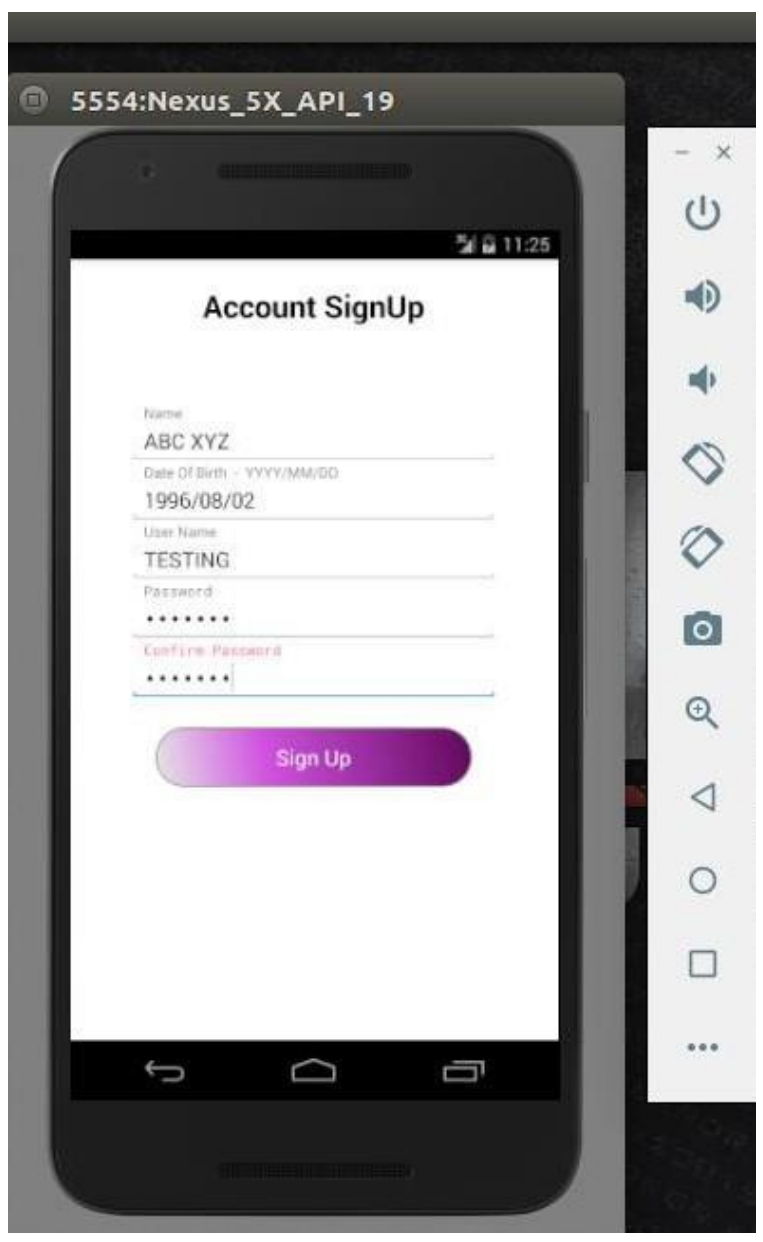

Fig 3: signing up in an app 


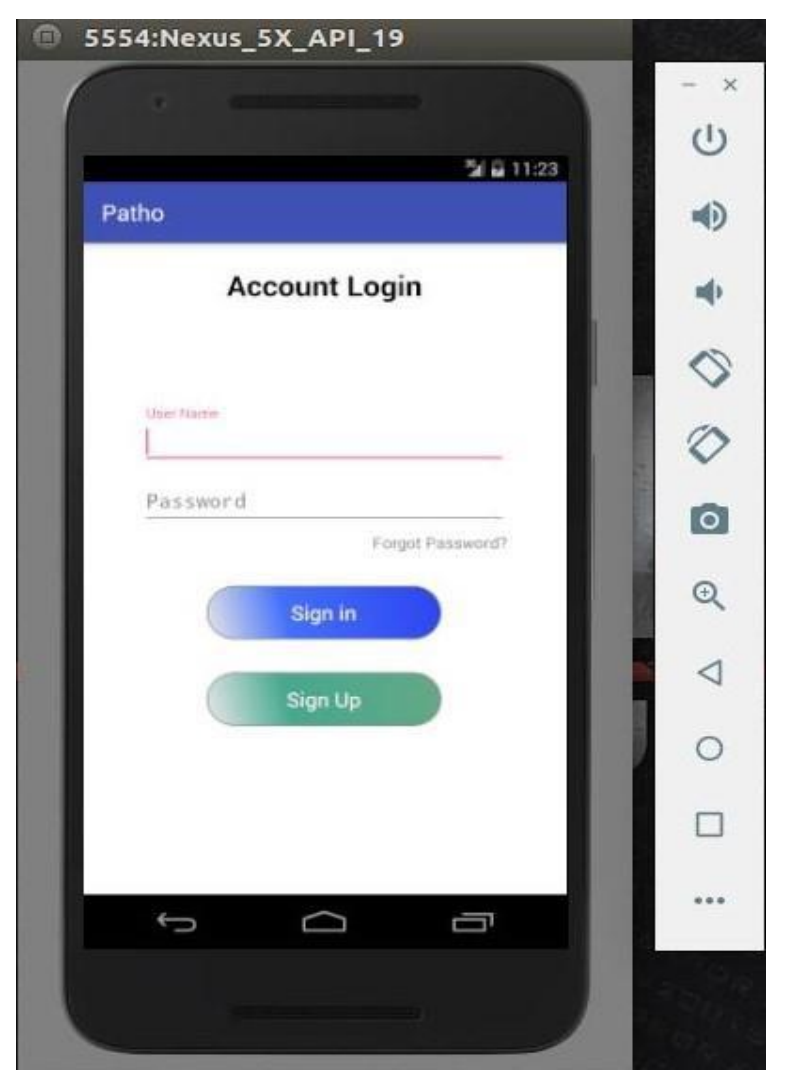

Fig 4: signing in an app

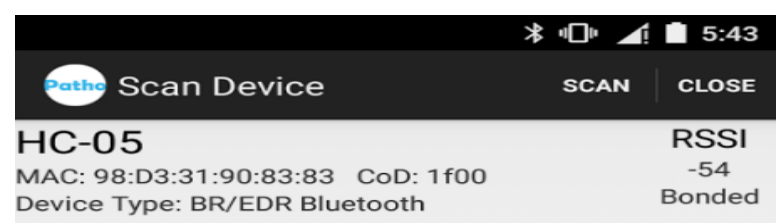

Select the device you need to connect

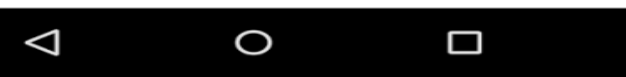

Fig 5. Scanning Device

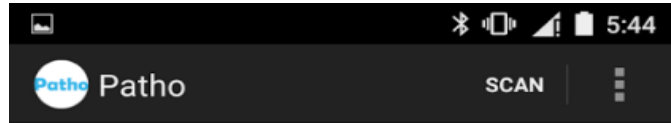

Connect the device:

Device name: $\mathrm{HC}-05$

Mac addr: 98:D3:31:90:83:83

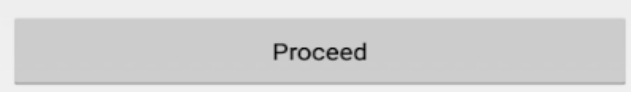

Successful connection

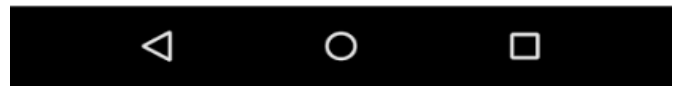

Fig 6 Connection with Hardware

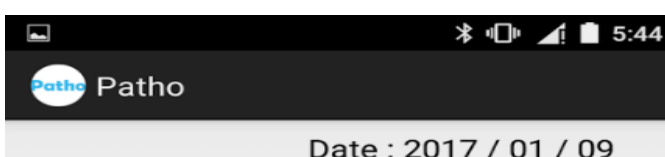

$\begin{array}{ll}\text { Name } & \text { Abc Xyz } \\ \text { Age } & 50\end{array}$

Select Test Parameter

$\square$ Hemoglobin

$\square$ Thyroid

$\checkmark$ Glucose

$\square$ Cholesterol

$\square$ Complete Blood Count

$\square$ Differential Counnt

\section{SUBMIT}

HOME

$\triangleleft \quad \bigcirc \quad \square$

Fig. 7 User Details 


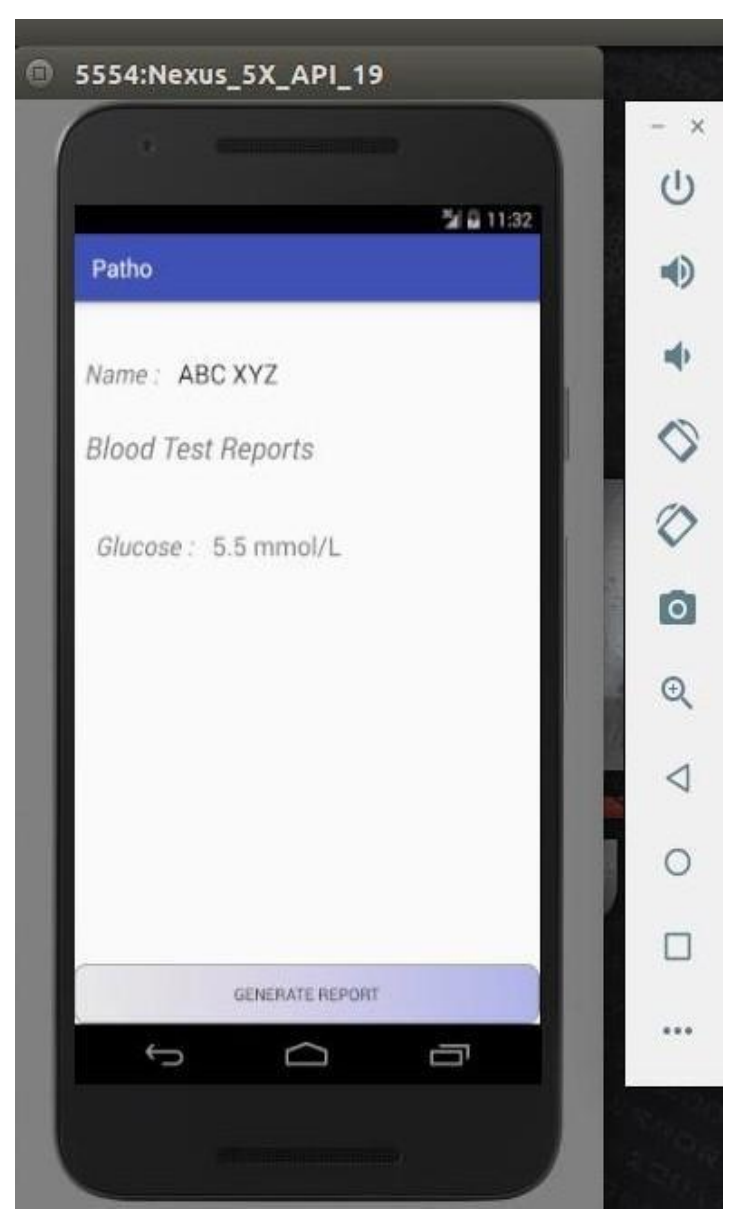

Fig 8 Blood Test Results

\section{CONCLUSION}

We have developed software which interfaces with hardware which take readings of particular tests. We have developed an android app which interfaces with the hardware, take reading from hardware and perform analysis and store in their phone database and on server. The results are available whenever required in the form of report in local database as well as on server.It helps the patients to understand the severity of disease and take further action.

\section{REFERENCES}

[1] Darwin Omar AlulemaFlores,Flavio PinedaLópez,Edwin Leonardo GarcíaAucatoma, Fabián
Eduardo IzquierdoCórdova," Automated System on Android platform for use in the implementation Psychotherapeutic Technical EMDR”,IEEE 2014

[2] C. Brendan S. Traw and Jonathan M. Smith,"Hardware / software Organization of a High- Performance ATM Host Interface", IEEE Journal on selected areas in communications, vol. 11, no.2, February 1993,page no.240-253.

[3] http://www.medicinenet.com/hemoglobin/page1.htm

[4] http://www.healthline.com/health/thyroid-functiontests\#Overview1

[5] https://medlineplus.gov/ency/article/003482.htm

[6] http://www.healthline.com/health/cholesteroltest\#Overview1

[7] Complete Blood Count: http://www.mayoclinic.org/testsprocedures/complete-blood-count/basics/definition/prc20014088

[8] http://en.wikipedia.org/wiki/Clinical_pathology

[9] https://www.ncbi.nlm.nih.gov/pubmedhealth/PMH00725 $34 /$

[10] http://www.urologymedicalgroup.com/health-library/hwview.php?DOCHWID=hw6580

[11] 'Textbook of Medical Laboratory Technology', 2e by Praful B. Godkar and Darshan P.Godkar

[12] https://www.diabetesselfmanagement.com/blog/what-isa-normal-blood-sugar-level/

[13] http://www.cholesterollevels.net/

[14] http://www.healthline.com/health/type-2diabetes/random-glucose-testing\#GlucoseTesting2

[15] http://www.cholesterolmenu.com/cholesterol-levelschart/

[16] http://www.healthywomen.org/condition/cholesterol

[17] https://labtestsonline.org/understanding/analytes/hdl/tab/t est/

[18] https://labtestsonline.org/understanding/analytes/ldl

[19] https://labtestsonline.org/understanding/analytes/triglycer ides/tab/test/

[20] http://www.healthline.com/health/wbc-count\#Results5 